УДК 659.118:005.346:004.738.5

DOI: https://doi.org/10.37320/2415-3583/19.4

Пащук О.Б.

спеціаліст

Інститут післядипломної освіти

Київський національний університет імені Тараса Шевченка ORCID: https://orcid.org/0000-0002-7221-9963

\title{
МЕТОДИКА ПРОСУВАННЯ ПРОДУКТУ У ВИСОКОКОНКУРЕНТНІЙ НІШІ НА МАРКЕТПЛЕЙСІ
}

Цифрові платформи продажу продуктів забезпечують зростаючі обсяги торгових операцій завдяки зручності вибору продукту для покупия, клієнтоорієнтованому сервісі, альтернативним варіантам продуктів для клієнтів. Цифрові торгові майданчики, або маркетплейси, забезпечують компанії інтегрованими у платформу інструментами просування продуктів, що автоматично веде до створення унікальних бізнес-моделей продажу в цифровому середовищі. Проте інтегровані інструменти просування за умови відсутності розуміння алгоритмів та принципів їх роботи не забезпечують стабільність продажів. Це потребує розроблення методики просування продукту на електронному ринку. Мета статті полягає в розробленні методики просування продукту у висококонкурентній ніші на маркетплейсі. В результаті вивчення практики просування продукту компанії Х сформовано методику просування продукту у висококонкурентній німі на маркетплейсі. Визначено, щчо для ефективного просування методика повинна включати ідентифікацію передумов та иілей просування продукту на ичифровій платформі, розроблення унікальної торгової пропозиції на основі переваг продукту, аналіз продукту конкурентів, визначення бюджету та стратегії просування продукту, вибір типів рекламних кампаній та інструментів просування кампанії. Для оцінювання ефективності запуску продукту та рекламних кампаній використовуються показники конверсії, рівня охоплення цільової аудиторії, CPC ("pay per click" - «вартість за клік»), CTR (рейтинг кліків, або клікабельність), відночення вартості реклами до продажів (Ad Cost Over Sales, ACOS), частки витрат конкурентів на рекламу (Share of Spend, SOS) та планової частки продажу продукту на ринку (SOM). Перерозподіл рекламних інвестицій між вибраними рекламними кампаніями забезпечує досягнення планового обсягу продажу завдяки вкладенням у найбільш ефективні інструменти. Визначено, щзо перерозподіл рекламних інвестииій дочільно здійснювати у поточному періоді для досягнення стратегічних иілей просування, таких як забезпечення планової частки ринку за планових інвестицій у випуск, просування продукту на електронному ринку.

Ключові слова: просування продукту на маркетплейсі, ицирові торгові платформи, стратегї просування на маркетплейсі, циифрові майданчики.

Постановка проблеми. Цифрові торгові майданчики, або маркетплейси (Amazon, Alibaba, Farfetch), зумовили виникнення інноваційних бізнес-моделей продажу, доставки продуктів та забезпечили зростання електронної комерції. За даними Digital Commerce 360, у 2020 році на 100 онлайн-платформах продано продуктів на 2,67 трильйонів доларів у всьому світі, 3 яких 62\% припали на платформи Amazon, Alibaba, eBay тощо. На Taobao, Tmall и Amazon припадає дві третини продажів у світовому масштабі у 2020 році. Валові продажі товарів виросли на 29\% порівняно 3 2019 роком. 50 цифрових платформ розміщені у США, які у 2020 році забезпечили зростання прибутків на 40\% [8]. Amazon займає найбільшу частку світового ринку за кількістю візитів користувачів у 2020 році, а саме 9,04\% [9]. Ріст продажів на цифрових платформах $є$ висхідним трендом, тому просування продукту на маркетплейсі потребує формування методики для розуміння основних етапів, рекламних інструментів та способів досягнення цілей.

Аналіз останніх досліджень і публікацій. У науковій літературі просування продуктів на цифрових платформах розглядається у роботах І.О. Ковшова, А.О. Дериколенко [1; 2], Л.В. Капінус [3], М.О. Глуміліна [4], Л.Г. Мельник [5], О.I. Хоменко [6], А.С. Шпіляк, Є.В. Гнітецький [7]. У дослідженнях 
систематизовано переваги просування на маркетплейсах, фактори посилення конкуренції на платформах, сформовано модель торгівлі, описано інструменти просування (зокрема, для збільшення трафіку та конверсії лістингу товарів). Проте в науковій літературі відсутні практичні приклади просування продукту на маркетплейсі, зокрема у висококонкурентній ніші. В результаті цього відсутня розроблена методика просування, що включає передумови запуску продукту на ринок; цілі та завдання; унікальну торгову пропозицію; процес формування бюджету та стратегії просування; розроблення рекламної кампанії та вибір набору інструментів реклами продукту відповідно до кампанії.

Мета статті полягає у розробленні методики просування продукту у висококонкурентній ніші на маркетплейсі.

Для досягнення поставленої мети визначено такі завдання:

1) виявлення передумов, цілей просування продукту на цифровій платформі;

2) розроблення унікальної торгової пропозиції на основі переваг продукту та аналізу продукту конкурентів;

3) розроблення бюджету та визначення стратегії просування продукту;

4) формування рекламних кампаній та визначення інструментів просування для кожної кампанії.

Виклад основного матеріалу. Компанія X займається електронною торгівлею на платформі Amazon 32016 року і здійснила успішні запуски понад 100 продуктів в низько- i середньоконкурентних нішах. На початку 2021 року компанія прийняла рішення запустити продукт у ніші з понад 500 тисяч конкурентів та досягла планових результатів продажів. Результативність запуску та виконання планів продажів залежали від вибраного продукту, рекламної кампанії, яка забезпечила правильне позиціонування, донесення цінності продукту покупцю та диференціацію продукту на ринку.

Основною метою компанії під час випуску продукту $є$ досягнення частки ринку (Serviceable Obtainable Market (SOM)) у розмірі 1\% і виведення ключових запитів у 100 пріоритетних запитах під час пошуку покупцем у мережі Інтернет.
Після ідентифікації цілі сформовано унікальну торгову пропозицію (Unique Selling Point (USP)) на основі ключових переваг продукту. Насамперед ми визначили ключові переваги нашого продукту та сформували USP поєднано з наявними в торговій категорії ключовими запитами покупця. Це забезпечило зосередження на перевагах продукту 3 оптимальним співвідношенням кількості пошукових запитів та конкуренції в ніші. Торгова пропозиція дала змогу позиціонувати продукт на основі переваг, зосередити рекламну кампанію на найбільш вигідній території (ніші) та уникнути конкурентної боротьби продукту на основі його слабких сторін (недоліків). Торгова пропозиція чітко відображена в креативних матеріалах, зокрема якісному лістингу фото- та відеоконтенту і копірайту для забезпечення максимальної релевантності пошукового запиту продукту та високої конверсії (рис. 1). Під релевантністю розуміємо (від лат. "relevo" - «полегшувати», «піднімати») визначену пошуковим алгоритмом міру відповідності результатів пошуку в пошуковій системі завданню, що визначене в пошуковому запиті. Релевантність із технічної точки зору означає пропорцію ключових слів або пошукових фраз користувача в тексті та їх відповідність певним пошуковим запитам. Під конверсією розуміємо цільову дію користувача або відвідувача лістингу (купівля продукту, реєстрація на сайті, запит на зворотній зв'язок, відгук про продукт тощо). Конверсія вимірюється як відношення кількості користувачів, які здійснили цільову дію, до кількості відвідувачів. Під лістингом розуміємо сторінку, на якій розміщено інформацію про продукт.

Після визначення цілі, розроблення унікальної торгової пропозиції на основі переваг, розроблення креативних матеріалів та лістингу продукту компанія формує рекламний бюджет на основі аналізу конкурентів. Успішний запуск продукту залежить від обсягу бюджету та стратегії просування. Розрахунок необхідного обсягу коштів у запуск продукту проведено на основі оцінювання частки витрат конкурентів на рекламу (Share of Spend, SOS) та планової частки продажу продукту на ринку (SOM). Розрахунок частки продажу продукту у розмірі 1\% здійснено на основі такої формули: 


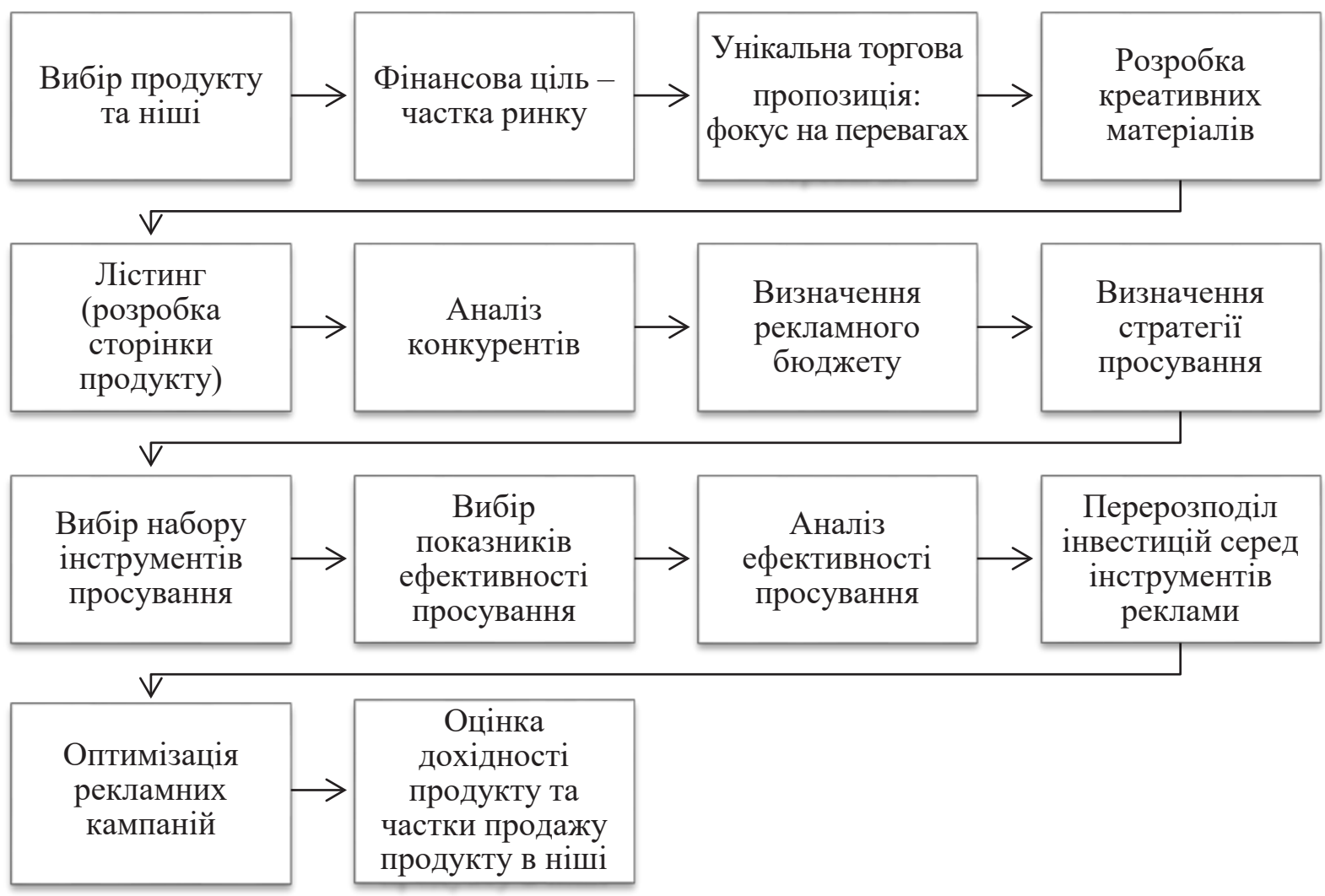

Рис. 1. Методика просування продукту на цифровій платформі «Амазон»

Джерело: розроблено автором

SOM = Цільовий обсяг продажів

(Sales Target) / Обсяг продажів продукту на ринку (Total Sales Market).

SOS розраховано як таке співвідношення: SOS = Інвестиції у медіа/рекламу продукту (Product Media Investments) / Інвестиції ринку у рекламу продукту (Market Media Investments).

Важливим $є$ розуміння ризику недосягнення визначеної частки продажів продукту на ринку (SOM) під час фінансування у рекламу на рівні конкурентів, тому інвестиції в рекламу повинні перевищувати обсяги вкладень конкурентів, що означає застосування агресивної рекламної кампанії (агресивної стратегії просування). Для визначення необхідного обсягу інвестицій використано підвищуючий коефіцієнт 1,4, отже, для досягнення частки ринку в розмірі $1 \%$ потрібно інвестувати 1,4\% від медіаінвестицій усієї категорії.

Після вибору стратегії просування та формування рекламного бюджету здійснено вибір набору інструментів просування 3 відповідними показниками ефективності просування.
Для ефективності реклами потрібно підібрати правильні проморішення, відповідні визначеним завданням реклами. Формування набору інструментів просування відбувається з поступовим коригуванням відповідно до ефективності кожного інструменту. Набір інструментів на етапі запуску продукту може відрізнятися від набору інструментів на етапі продажу. Це зумовлено відсутністю достатньої інформації про категорію, в якій відбувається запуск продукту, та пояснює потребу у виборі кількох інструментів просування. Запуск продукту компанії X здійснено 3 використанням таких рекламних кампаній для таргетування продукту.

1) Рекламна кампанія РРС (рекламні товари, Sponsored Product - рекламний таргетинг на рекламні продукти), яка здатна забезпечити високий рівень охоплення цільової аудитоpiï та має широкі можливості налаштування. Для створення рекламної кампанії потрібно визначити іii тривалість і бюджет, ключові слова або встановити в налаштуваннях платформи автоматичне визначення ключових слів 
(«Амазон» автоматично підбирає під рекламне оголошення пошукові терміни користувачів), вибрати товари та визначити ставку. Для таргетування продукту використано такі напрями, як таргетування за релевантними ключовими запитами на основі сегментів за кількістю пошукових запитів (Main Part); таргетування продукту на основі автоматизованого пошуку нових ключових запитів (Growth Part); таргетування продукту (Product Targeting Part).

Таргетування за релевантними ключовими запитами (Main Part) - це напрям, який включає таргетування за релевантними ключовими запитами, розділеними на сегменти/ кластери за кількістю пошукових запитів на високо-, середньо-, низькочастотні для контролю бюджету та місця розташування. Кожному сегменту продукту відповідала окрема рекламна кампанія. Таргетування продукту на основі точного типу відповідності ключовим словам відповідно до їх частоти появи у пошуковій системі допомагає ключовим запитам швидко зростати в органічній видачі. Таким чином, розроблено такі рекламні кампанії:

- 3 найбільш релевантними ключовими словами (Top Performing Keywords (TPK Exact)), куди включено високочастотні ключові запити з найбільшою конкурентоспроможністю та найвищим обсягом трафіку; на цю рекламну кампанію спрямовано 70\% рекламного бюджету;

- iз середньочастотними пошуковими запитами, що формують другу рекламну кампанію під назвою Exact Simple;

- 3 низькочастотними пошуковими запитами, що формують рекламну кампанію під назвою Other Simple.

Таргетування продукту на основі автоматизованого пошуку нових ключових запитів (Growth Part) передбачає розроблення рекламних кампаній, які повинні відповідати умові належного додавання нових ключових слів до рекламних кампаній Growth Part, як "Negative Exact". Таким чином, платформа Amazon уникатиме автоматичного дублювання ключових слів та здійснюватиме пошук потрібних ключових слів покупців для забезпечення зростання цільової аудиторії. Ці рекламні кампанії є своєрідними «чорними скриньками» (“Black Box"), які здійснюють пошук ключових слів, що відсутні у рекламних кампаніях. Компанія зробила акцент на двох напрямах, таких як "Broad Negative" та "Auto Negative".

Таргетування продукту Product Targeting Part розділено на такі три частини, як таргетування за унікальним ідентифікатором продукту (ASINs); таргетування за категоріями продукту (Categories); таргетування за брендами продукту (Brands). Amazon Standard Identification Number, ASIN (стандартний ідентифікаційний номер «Амазон») - це 10-символьний буквено-цифровий унікальний ідентифікатор продукту.

Таргетування за унікальним ідентифікатором продукту відбувалося через ASINs інших гравців на ринку, порівняно $з$ якими компанія X мала конкуренту перевагу. Ідентифікатори продукту вибрано за критерієм ціни: ціна конкурентів вища ціни продукту компанії X; ідентифікатори продукту ASINs iз поганими рейтингами; ASINs, які продають продукт компанії X 3 використанням автоматичної рекламної кампанії тощо. Категорії (Categories) - це таргетинг продукту за категоріями, які найбільш актуальні для вибраного продукту. Важливо додавати усі ASINs iз попередніх кампаній у Negative Targeting для уникнення дублювання в кампаніях. Під час таргетування за брендами продукту (Brands) кампанії включають ключові слова 3 брендами конкурентів. Компанія X використала цей тип кампанії для захисту власного бренду та «перехоплення» трафіку конкурентів.

2) PPC (Sponsored Display - Product Targeting - рекламний таргетинг у медійній рекламі) - це таргетування на основі ідентифікаторів продукту ASINs подібно рекламній кампанії "Sponsored Product”, перевагою якого є більш вигідне розміщення на лістингах конкурентів. ASINs вибрано за такими ж критеріями, як у рекламній кампанії "Sponsored Product - Product Targeting Part".

Головна відмінність між таргетуванням "Sponsored Products Product Targeting" та таргетуванням "Sponsored Display Product Targeting" - це розміщення в оголошеннях. Рекламний таргетинг на рекламні продукти показує рекламу на сторінці 3 деталями товару, а також в основних результатах пошуку. Рекламний таргетинг у медійній рекламі суворо розміщується на сторінці 
деталей продукту, на який компанія націлена для розміщення на Amazon.

3) Sponsored Brand Video використовується для збільшення рівня впізнавання бренду серед користувачів, що забезпечує високу якість контакту, низький СРС (“pay per click” - «вартість за клік», що є рекламною моделлю, яка працює в Інтернеті, де рекламодавець розміщує рекламу на сайтах і сплачує їх власникам за натискання користувачем на розміщений банер або «тіло» документа), дуже високий CTR (рейтинг кліків, або клікабельність, тобто відношення числа кліків користувачів на оголошення до числа його показів у відсотках; показник використовується для вимірювання ефективності онлайн-реклами для веб-сайту чи рекламних кампаній). Рекламні оголошення розміщуються на основі ключових слів, ціни за клік та безпосередньо зв'язують покупця зі сторінкою відомостей про продукт.

4) Роздачі за ключовими запитами за допомогою автоматизованих платформ та кешбексервісів. Цей інструмент сприяє швидкому підняттю ключів у пошуковій видачі, автома- тизовані сервіси допомагають економити час та мають власний стабільний трафік.

5) Роздачі за відгуки використовуються для швидкого формування довіри до продукту i, як наслідок, оптимізації вартості реклами відносно продажів (Ad Cost Over Sales, ACOS).

За результатами першого тижня кампанії компанія $\mathrm{X}$ перерозподілила рекламні інвестиції між вибраними рекламними кампаніями, підсилюючи найбільш ефективні інструменти. В перший тиждень рекламної кампанії важливо дати достатньо часу на навчання машинному інтелекту Amazon для визначення цільових аудиторій, які позитивно реагують на продукт, i не вимикати рекламні кампанії, які ще не набрали статистично значимих даних.

В результаті запуску рекламних кампаній, згідно з підсумками першого кварталу після запуску, продукт досягнув поставленої мети продажів 1\% в рамках наявного рекламного бюджету. В ході оптимізації рекламних кампаній і зміни пропорції інвестицій всередині рекламних медіа після першого місяця

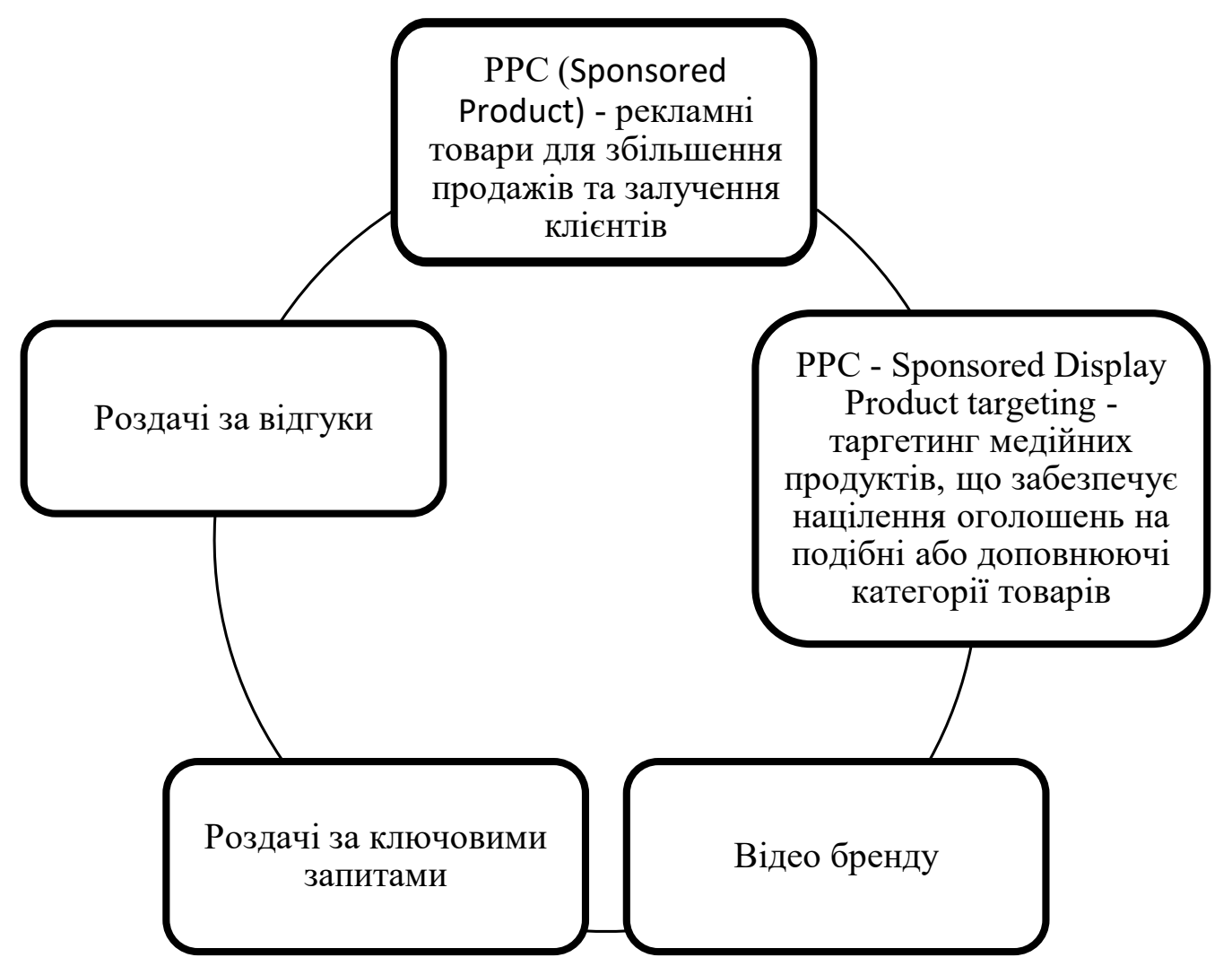

Рис. 2. Типи рекламних кампаній для просування продукту на платформі «Амазон» 
було вдвічі зменшено вартість реклами відносно продажів (Ad Cost Over Sales, ACOS) i виведено продукт на плановий рівень дохідності. Продукт став помітним і затребуваним на платформі Amazon.

Висновки. У дослідженні сформовано методику просування продукту у висококонкурентній ніші на маркетплейсі, яка включає такі основні компоненти, як передумови та цілі просування продукту на цифровій платформі; унікальна торгова пропозиція на основі переваг продукту; аналіз продукту конкурентів; бюджет і стратегія просування продукту; типи рекламних кампаній та інструменти просування кампанії. Для успішності запуску продукту на цифровій платформі та досягнення фінансових цілей (досягнення частки продажу продукту в ніші) обов'язковим $\epsilon$ розуміння особливостей рекламних кампаній, які пропонуються на платформі та забезпечують різну ефективність. Для оцінювання ефективності запуску продукту та рекламних кампаній використовуються показники конверсії, рівня охоплення цільової аудитоpiï, CPC ("pay per click" - «вартість за клік»), CTR (рейтинг кліків, або клікабельність), відношення вартості реклами до продажів (Ad Cost Over Sales, ACOS), частки витрат конкурентів на рекламу (Share of Spend, SOS) та планової частки продажу продукту на ринку (SOM). Перерозподіл рекламних інвестицій між вибраними рекламними кампаніями забезпечує досягнення планового обсягу продажу завдяки вкладенням у найбільш ефективні інструменти. Подальші дослідження доцільно спрямувати на вивчення стратегічних маркетингових інструментів просування продукту на маркетплейсі, розроблення методики побудови системи продажів на великих торгових майданчиках, оцінювання ефективності просування продукту на великих торгових майданчиках.

\section{Список використаних джерел:}

1. Дериколенко А.О. Просування продукції промислових підприємств за допомогою інструментарію цифрового маркетингу : дис. ... канд. екон. наук : спец. 08.00.04 ; наук. керівник Л.Г. Мельник ; Харківський політехнічний інститут. Харків, 2021. 245 с.

2. Дериколенко А.О. Інтернет-платформа як основа ефективного просування продукції промислових підприємств. Механізм регулювання економіки. 2020. № 1. С. 116-123.

3. Капінус Л.В., Лабінська Н.О., Скригун Н.П. Маркетингова поведінка покупців товарів у маркетплейсі. Проблеми системного підходу в економіці. 2020. № 2(76). С. 154-160.

4. Ковшова I.О., Глуміліна М.О. Маркетингове коригування поведінкових стереотипів споживачів на ринку маркетплейсів України. Підприємництво і торгівля. 2021. № 29. С. 20-27.

5. Мельник Л.Г., Дериколенко А.О. Парадигмальний базис (концептуальні основи) просування товарів промислових підприємств за допомогою інструментарію цифрового маркетингу в умовах глобалізації. Агросвіт. 2020. № 12. C. 34-41. DOI: 10.32702/2306-6792.2020.12.34

6. Хоменко О.І. Маркетплейси та їх значення для електронної торгівлі. Актуальні проблеми та перспективи розвитку маркетингового управління : тези доповідей VI Всеукраїнської наукової конференції молодих учених та студентів (м. Київ, 5 квітня 2019 року). Київ : КНУТД, 2019. С. 15-16.

7. Шпіляк А.С., Гнітецький Є.В. Інструментарій просування товару на платформі Amazon. Актуальні проблеми економіки та управління. 2018. Вип. 12. URL: https://ela.kpi.ua/handle/123456789/2 4663?locale=uk (дата звернення: 17.03.2021).

8. Ali F. What are the top online marketplaces? 2021. URL: https://www.digitalcommerce360.com/article/ infographic-top-online-marketplaces (accessed 01 July 2021).

9. Statista leading online marketplace websites worldwide in 2020, based on share of visits. 2021. URL: https://www.statista.com/statistics/1198949/most-visited-websites-in-the-retail-sector-worldwide (accessed 01 July 2021).

\section{References:}

1. Derikolenko A.A. (2021) Prosuvannia produktsii promyslovykh pidpryiemstv za dopomohoiu instrumentariiu tsyfrovoho marketynhu [Promotion of industrial enterprises with the help of digital marketing tools]: abstract of Ph.D. dissertation, National technical Kharkiv Polytechnic University. Kharkiv. (in Ukrainian)

2. Derykolenko A.O. (2020). Internet-platforma yak osnova efektyvnoho prosuvannia produktsii promyslovykh pidpryiemstv [Internet platform as a basis for effective promotion of industrial enterprises]. Mekhanizm rehulyuvannya ekonomiky, no. 1, pp. 116-123. 
3. Kapinus L.V., Labinska N.O., Skryhun N.P. (2020) Marketynhova povedinka pokuptsiv tovariv u marketpleisi [Marketing behavior of buyers of goods in the marketplace]. Problemy systemnoho pidkhodu v ekonomitsi, no. 2(76), pp. 154-160.

4. Kovshova I.O., Hlumilina M.O. (2021) Marketynhove koryhuvannia povedinkovykh streotypiv spozhyvachiv na rynku marketpleisiv Ukrainy [Marketing correction of behavioral stereotypes of consumers in the marketplace of Ukraine]. Pidpryiemnytstvo i torhivlia, no. 29, pp. 20-27.

5. Melnyk L.G., DerikolenkoA.A. (2020) Paradigmatic basis (conceptual bases) of promotion of the goods of the industrial enterprises by means of tools of digital marketing in the conditions of globalization [Paradigmatic basis (conceptual basis) of promotion of goods of industrial enterprises with the help of digital marketing tools in the context of globalization]. Agrosvit, vol. 12, pp. 34-41. DOI: 10.32702/2306-6792.2020.12.34

6. Khomenko O.I. (2019) Marketplaces and their significance for e-commerce [Marketplaces and their importance for e-commerce]. Aktual'ni problemy ta perspektyvy rozvytku marketynhovoho upravlinnya. Kyiv National University of Technology and Design, pp. 15-16.

7. Shpilyak A.S., Gnitetsky E.V. (2018) Instrumentarii prosuvannia tovaru na platformi Amazon [Tools for product promotion on the platform Amazon]. Aktual'ni problemy ekonomiky ta upravlinnya, vol. 12. Available at: https://ela.kpi.ua/handle/123456789/24663?locale=uk

8. Ali F. (2021) "What are the top online marketplaces?". Available at: https://www.digitalcommerce360.com/article/infographic-top-online-marketplaces (accessed 01 July 2021).

9. Statista (2021) "Leading online marketplace websites worldwide in 2020, based on share of visits". Available at: https://www.statista.com/statistics/1198949/most-visited-websites-in-the-retail-sectorworldwide (accessed 01 July 2021).

Pashchuk Olha

Institute of Postgraduate Education

Taras Shevchenko National University of Kyiv

\section{METHODOLOGY FOR PRODUCT PROMOTION IN A HIGHLY COMPETITIVE MARKETPLACE NICHE}

Digital product sales platforms provide a growing volume of commerce through convenient product selection for the customer, customer-centric service, and alternative product options for customers. Digital marketplaces or marketplaces provide companies with platform-integrated product promotion tools, automatically leading to the creation of unique business models for selling in a digital environment. However, integrated promotion tools in the absence of an understanding of the algorithms and principles of their work do not ensure stable sales. This requires the development of a methodology for product promotion in the electronic market. The aim of the article was to develop a methodology for product promotion in a highly competitive niche on the marketplace. As a result of studying the practice of promoting the product of company $X$, the methodology of product promotion in a highly competitive niche on the marketplace was formed. It was determined that for effective promotion methodology should include: identification of the prerequisites and objectives for promoting the product on the digital platform; development of a unique selling proposition based on product preferences; competitor product analysis; determination of the budget and promotion strategy for the product; selection of types of advertising campaigns and campaign promotion tools. To estimate the efficiency of the product launch and advertising campaigns the following indicators are used: conversion rates, the target audience coverage level, CPC (Payperclick), CTR (click-through rate or clickability), the relationship between the cost of advertising and sales (AdCostOverSales, ACOS), the competitors'share of advertising expenses (ShareofSpend, SOS) and the target market share for the product (SOM). Redistribution of advertising investments between the selected advertising campaigns ensures the achievement of the planned sales volume by investing in the most effective tools. It is determined that redistribution of advertising investments is expedient in the current period to achieve the strategic goals of promotion - ensuring the planned market share of planned investments in output, promotion of the product in the electronic market.

Key words: product promotion on marketplaces, digital trading platforms, strategies for promotion on marketplaces, digital platforms.

JEL classification: G15, E64, H54 